\title{
Carbon partitioning in the food web of a high mountain lake: from bacteria to zooplankton
}

\author{
Cristiana CALLIERI*, Alessandra PUGNETTI and Marina MANCA
}

C.N.R. Istituto Italiano di Idrobiologia, 28922 Verbania-Pallanza, Italy

*e-mail correspondig author: c.callieri@iii.to.cnr.it

\begin{abstract}
The organisms of the microbial loop in Lake Paione Superiore (LPS), a high mountain lake in the Italian Alpine region, were studied together with phytoplankton and zooplankton for three successive years. The biomass of bacteria, HNF (heterotrophic nanoflagellates), ciliates and phytoplankton, as mean carbon concentration in the three years, was 30 and $37 \mu g C^{-1}$ near the surface (SUR) and the bottom (BOT) respectively. Under the ice-cover the mean biomass carbon decreased especially at the BOT, whereas at SUR the decrease was less evident due to the maintenance of higher phytoplankton biomass (mixotrophic flagellates). In LPS $\sim 50 \%$ of the carbon was confined in bacteria, $20 \%$ in protozoa and $30 \%$ in phytoplankton. The ratio Autotrophs/Heterotrophs was lower than 1 (mean: 0,97 at SUR and 0,58 at BOT) thus indicating a system with a predominance of the heterotrophs. This might be the result of light inhibition of algal growth coupled to a production of dissolved carbon, utilized by bacteria. During late summer the peak of Daphnia longispina, the main component of the zooplankton of LPS, increased the carbon content in the lake to a total of 158 and $300 \mu \mathrm{g} \mathrm{Cl} l^{-1}$ in 1997 and 1998 respectively. At the late summer peaks, zooplankton represented from 78 to $89 \%$ of the total carbon of the pelagic communities. Furthermore, the presence of Daphnia could be responsible for a decrease in the biomass carbon of a variety of organisms (algae, protozoa and bacteria). It may be possible that this is an instance of zooplankton grazing on algae, protozoa and also bacteria, as Daphnia has very broad niches and may eat pico-, nanoplankton and small ciliates. In the oligotrophic LPS, a diet which also includes protozoa could give Daphnia a further chance of survival, as ciliates are an important source of fatty acids and sterols.
\end{abstract}

Key words: microbial loop, high mountain lake, phytoplankton, zooplankton

\section{INTRODUCTION}

Since the importance of the microbial loop in ecosystem functioning was recognized (Pomeroy 1974; Williams 1981; Sieburth \& Davis 1982; Azam et al. 1983), limnologists have devoted more and more effort to studying this part of the food web. Researches focussed on standing stock quantification (Amblard et al. 1995; Hadas \& Berman 1998) and on carbon flux measurements in the loop (Weisse 1990; Nagata 1988, Nagata et al. 1996; Amblard et al. 1994; Šimek et al. 1995). Micro and mesocosm experiments were performed (Jürgens 1994; Jürgens et al. 1997) to investigate the food linkage among metazoans, protozoans and the bacterial population. Different studies emphasized the interactions among microorganisms and organisms in the microbial and classical food web in lakes (see review by Jürgens 1994; Pace et al. 1990; Carrick et al. 1991; Mathes \& Arndt 1995; Šimek et al. 1997). Nevertheless, information is limited on carbon partitioning of natural assemblages of all the components of the microbial loop and zooplankton simultaneously (Porter 1996). Stockner \& Porter (1988) outlined the different efficiency in carbon transfer in two food chains, one dominated by Daphnia and the others by picoplankton and microheterotrophs: the longer the chain the higher the losses. The microbial loop may be a sink for energy flow, as much carbon is respired at different trophic levels so that the chain tends to support a lower standing stock of fish. But what happens if in the lake there are no fish at all, the water is acid, cold, ice-covered for five-six months and with a clear, light-unprotected water column?

This question prompted us to begin a study of the entire food web, from bacteria to zooplankton, of a simplified high mountain lake ecosystem which was slightly acid in 1991-1993 (Mosello et al. 1993), to quantify the carbon in the different compartments of the food web. The study constitutes the part of the EU MOLAR Project involved in Pelagic Food Web Research. Specifically, this was a three-year study on the pelagic community composition of the high mountain lake: Lake Paione Superiore (LPS) in the Italian Central Alps above $2000 \mathrm{~m}$ (Mosello et al. 1993, 1994). The absence of fish, the simplification of the other compartments with relatively few species and the almost exclusive presence of Daphnia in the summer zooplankton population (Cammarano \& Manca 1997) made this small lake unique for studying the microbial loop and its relationship with Daphnia and phytoplankton.

In this paper we will mainly discuss the carbon partitioning in the food web during a three-year study, comparing the carbon content of the different autotrophic and heterotrophic compartments in the ice-free and ice-cover periods. In a more detailed paper published in 
this issue (Callieri \& Bertoni 1999) the study of the dynamics of the components of the microbial loop will be described also in relation to changes in $\mathrm{pH}$ and the light climate. Another paper will show the results of the activity measurements of autotrophic production, bacterial production and protozoan grazing (Callieri \& Bertoni, in preparation).

\section{MATERIALS AND METHODS}

Field samplings were performed monthly from July 1996 to October 1998 at the point of maximum depth (11.7 m) of Lake Paione Superiore (LPS), a small glacial cirque lake at an altitude of $2269 \mathrm{~m}$ in the Bognanco Valley (Pennine Alps, Italy) (Bianchini 1952). Its geographic and morphometric features, together with the hydrochemical variables measured in 1991-1994, were reported in synthesis by Cammarano \& Manca (1997). More recent data on water chemistry can be found in The MOLAR Water Chemistry Group (1999, this issue). A light extinction profile during summer and winter is presented by Callieri \& Bertoni (in prep.). The water column is well irradiated, with $12 \%$ of surface irradiance present at the bottom. The measurements of underwater light, as PAR $\left(\mu \mathrm{E} \mathrm{m}^{-2} \mathrm{~s}^{-1}\right)$, were performed with a LI-COR 250, and the extinction coefficient $(\mathrm{k})$ was $0.22-0.32 \mathrm{~m}^{-1}$ in summer. The $\mathrm{k}$ values measured in 1991-93 were 0.1-0.2 $\mathrm{m}^{-1}$ (Bettinetti 1994; Pugnetti \& Bettinetti 1995). The temperature in August is around $14{ }^{\circ} \mathrm{C}$ and a stratification appeared in August 1997 and July 1998.

During the ice-free period, we sampled picoplankton, protozoa, phytoplankton and zooplankton at two depths, namely, one meter under the surface in summer (SUR) and one meter above the bottom (BOT). Except for zooplankton, on which information was already available, we also collected samples under the ice-cover (one meter under the ice-water interface and one meter above the bottom). Zooplankton net integrated samples were also collected on each date in replicates, to obtain the carbon biomass directly from dry weight and carbon content (for details see Manca \& Comoli 1999, this issue). To fix and count bacteria or HPP (heterotrophic picoplankton), APP (autotrophic picoplankton), HNF (heterotrophic nanoflagellate), phytoplankton and ciliates, the protocols described by Straškrabová et al. (1999, this issue) were followed, to obtain results comparable with the other lakes included in the MOLAR project. One exception was the dyeing of bacteria, which was done using Acridine Orange instead of DAPI, and the use of Anopore filters instead of $\mathrm{Nu}$ clepore membranes of the same porosity $(0.2 \mu \mathrm{m}$ pore size diameter) (Straškrabová et al. 1999, this issue). All the counting and biovolume measurement data were converted to carbon using the conversion factors and the equations reported in the protocols (Straškrabová et al. 1999, this issue). The statistical analyses performed were ANOVA tests.

\section{RESULTS}

In figure 1 the biomass temporal variations of HPP, APP, HNF, ciliates, phytoplankton and zooplankton are shown at SUR and BOT depths respectively. The depth of the BOT changed as the lake level fluctuated: in winter it was 7-8 $\mathrm{m}$ and in summer $9-10 \mathrm{~m}$. These depths guaranteed sampling without contamination due to sediment resuspension.

APP, both eukaryots and cyanobacteria, were almost absent, reaching a maximum value of $0.1 \mu \mathrm{g} \mathrm{C}{ }^{-1}$. On these rare occasions they were small eukaryotic algae, as picocyanobacteria were absent. Stockner \& Shortreed (1991) have reported a situation of complete absence of pico-blues and dominance of eukaryotic picoplankton in low $\mathrm{pH}$, humic Danish lakes. Both the acid conditions of LPS waters and the possibility of PAR and UV inhibition at $2200 \mathrm{~m}$ could be evoked as the possible causes of the absence of picocyanobacteria.

HPP (bacteria) constituted around 50\% of the carbon of the microbial food web (microbial loop plus phytoplankton) and their seasonal dynamics were quite similar at the two depths, with the sole exception of early summer 1998, when an isolated peak of $56 \mu \mathrm{gC}^{-1}$ was measured, due to the presence of large rods and long filaments at the BOT. Under the ice the bacterial carbon concentration was around $5 \mu \mathrm{g} \mathrm{C}^{-1}$, which nevertheless represents $40 \%$ of the organic carbon in the microbial food web. During early summer the bacterial carbon concentration, as a mean, was $36 \mu \mathrm{g} \mathrm{Cl}^{-1}$.

HNF showed a density range from $410^{4} 1^{-1}$ to $410^{6}$ $1^{-1}$ and were composed of a predominance of $<3 \mu \mathrm{m}$ cells and by 3 to $8 \mu \mathrm{m}$ cells, which were relatively more important but in low numbers, under the ice. In Callieri \& Bertoni (1999, this issue) the structure of the HNF population is described in more detail. Their carbon ranged from 0.4 to $42 \mu \mathrm{g} \mathrm{C} 1^{-1}$ and their mean concentration was 3 and $5 \mu \mathrm{g} \mathrm{C}{ }^{-1}$ at the two depths respectively. Here it is important to note that these flagellates were less abundant under the ice (range: 60-750 $10^{3} 1^{-1}$ ) than in summer (range: 250-17,260 $10^{3} 1^{-1}$ ), when an increase in size diversity and numbers was also observed. They decreased in correspondence with the September increase in zooplankton at the BOT. They were also very low in May-June 1998 at the ice melt.

Ciliate biomass was lower than HPP and phytoplankton. The carbon concentrations ranged from 0.01 to $12 \mu \mathrm{g} \mathrm{C}^{-1}$ with a mean of $2 \mu \mathrm{g} \mathrm{C}^{-1}$. During the winter ice-cover the ciliate carbon was very low at both depths, but the abundance of prostomatids with Urotricha spp. and of the oligotrich Halteria grandinella reached values of $1500-2000$ ind $1^{-1}$. Although the description of the ciliate species succession will be presented elsewhere (Callieri \& Bertoni 1999, this issue), by simply looking at their total biomass it is clear that, especially at BOT, their importance in terms of carbon is restricted to the ice-free period, when the oligotrichs are represented by the large Strombidium sp. At SUR a 


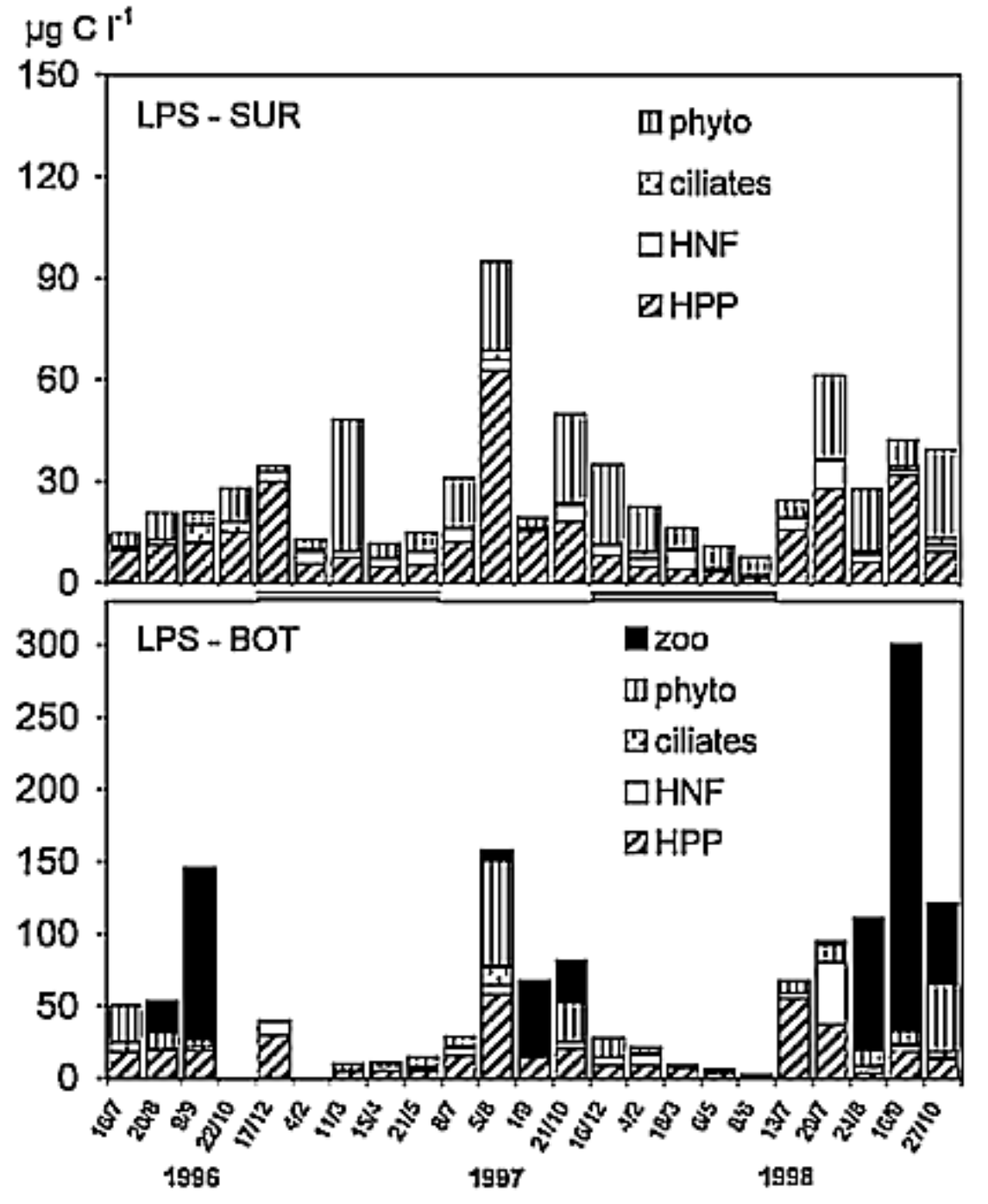

Fig. 1. Temporal variations of APP, HPP, HNF, ciliates and phytoplankton biomass, as carbon $\left(\mu \mathrm{g} \mathrm{C}^{-1}\right)$, at SUR (1 $\mathrm{m}$ under the surface) and BOT $(1 \mathrm{~m}$ above the bottom) of Lake Paione Superiore (LPS) during 1996, 1997, 1998. Double line indicates the icecover. peak of cilate carbon due to Halteria was observed just once under the ice (February '97). The presence of the small prostomatid Urotricha throughout the year is not visible in the graphs shown in figure 1 . The absence of large mixotrophic ciliates in LPS during winter constituted a significant difference from other MOLAR lakes. For example, comparing the carbon data of LPS with those from Lake Redó (Camarero \& Felip, personal comunication), in December 1996 it appears that while in the deeper part of the lakes similar concentrations were measured (0.2-0.3 $\mu \mathrm{g} \mathrm{C}^{-1}$; $11 \mathrm{~m} \mathrm{LPS}$ and $18 \mathrm{~m}$ Redó respectively), at $1 \mathrm{~m}$ in Lake Redó the carbon in the ciliate was more than one order of magnitude higher than in LPS.

Phytoplankton was mainly represented by: Chromulina sp., Dinobryon sertularia, Mallomonas alveolata and Gymnodinium sp., which were present throughout the year at both depths. Most of these species (Dino- bryon sertularia and also some species of Chromulina and Gymnodinium) are known from the literature to be potentially mixotrophic, showing facultative bacterial feeding (Porter 1988; Jones \& Rees 1994; Isaksson 1998). The phytoplankton carbon ranged from 1 to 38.9 $\mu \mathrm{g} \mathrm{l}^{-1}$, with a mean value of $11.5 \mu \mathrm{g} \mathrm{l}^{-1}$. As a general pattern the total phytoplankton dynamics are characterized by a decline that begins after some months of icecover (even though quite high values at the end of the period could be observed) and lasts until the end of the ice melting, by an increase during early summer, when the yearly maxima are usually attained, and by a late summer decrease. The results of the spatial and temporal species dynamics can be found in Pugnetti \& Bettinetti (1999, this issue). Chromulina sp., Mallomonas alveolata and Gymnodinium sp. were also the dominant species in the years 1991-1993 (Pugnetti \& Bettinetti 1995), while Dinobryon sertularia has greatly increased 
its importance in the present study. In comparison with the years 1991-1993 the total number of species has now increased (Pugnetti \& Bettinetti 1999, this issue).

Zooplankton biomass is always negligible in the surface samples, because of the benthic habits of zooplankton during the day. Biomass peaks vary from year to year, both in their absolute values and in their timing, reflecting meteorological conditions and the time of ice melt, which are responsible for the initial increase in the carbon confined in the microbial food web. The development of zooplankton starts after this phase of phytoplankton, protozoa and bacteria increase (Fig. 1, BOT). In August 1997, when nauplii and rotifers contribute most to the total zooplanktonic carbon, it is likely that no effect on the phytoplankton, protozoa and bacteria is evident. In July and at the beginning of August, when Daphnia carbon was low, the compartments of the microbial loop represented 49,77 and $85 \%$ of the total carbon in 1996, 1997 and 1998, at BOT. In the three consecutive years the importance of the microbial loop and in particular of bacteria increased, whereas the phytoplankton proportionally decreased. In late summer, both the autotrophic and the heterotrophic communities are preyed upon by Daphnia longispina, the main component of the zooplankton of LPS (Fig. 2) (Manca \& Comoli 1999, this issue). This pattern is particularly evident in September 1997 and August 1998 when the massive presence of Daphnia increased the carbon content in the lake to a total of 158 and $300 \mu \mathrm{g} \mathrm{C}^{-1}$ respectively. At the late summer peaks zooplankton represent from 78 to $89 \%$ of the total carbon of the pelagic communities. In August 1998 the earlier development of Daphnia reflects a more effective control on phytoplankton growth by a most efficient community of grazers. To quantify the carbon transfers in the food web due to the activities of various organisms, the positive increments of carbon in the zooplankton compartment and the concomitant negative ones, confined in the microbial loop and phytoplankton, were calculated (Fig. 3).

The first observation is that the presence of Daphnia is responsible for a decrease in the carbon of a variety of organisms. It may be possible that this is an instance of zooplankton grazing on algae, protozoa and bacteria too.

In terms of carbon the heterotrophic organisms like HNF, bacteria and ciliates taken separately are not as important as the mixotrophic algae, particularly at SUR. Nevertheless, by summing up the carbon from all the microbial heterotrophic compartments (ciliates, HNF and bacteria) and making a ratio with the phytoplankton $(\mathrm{A} / \mathrm{H}$, ratio), in the ice-free period the mean value is 0.68 at SUR and 0.65 at BOT, which in any case demonstrates the tendency of the system to confine more carbon to the heterotrophs. If we include also the zooplankton among the heterotrophs the ratio decreases to 0.33 , but only in September its contribution to the car- bon of the heterotrophic communities is significant. The ratio increases to a maximum of 4 during the ice-cover at SUR and also the mean value of the two ice-cover period is low (1.28).

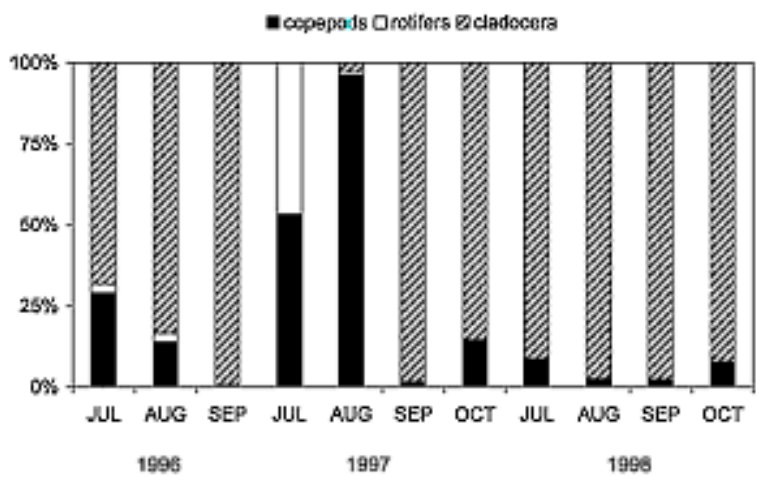

Fig. 2. Relative contribution of different groups to the total carbon biomass of zooplankton in the BOT samples $(1 \mathrm{~m}$ above the bottom) of Lake Paione Superiore in the three years under study.

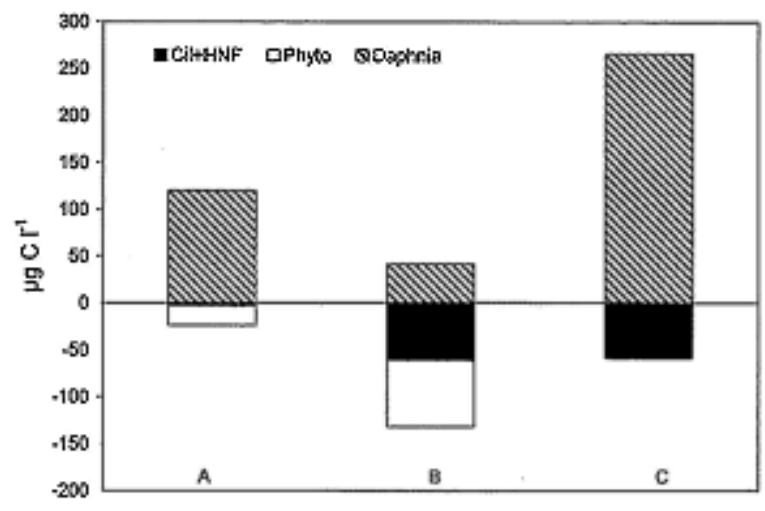

Fig. 3. Increments in the carbon $\left(\mu \mathrm{g}^{-1}\right)$ of the ciliates, HNF, phytoplankton and zooplankton calculated by the difference between two measurements, in three ice-free periods, at BOT (1 m above the bottom). A: July - September 1996; B: August - September 1997; C: July - September 1998.

From the three-year data, statistically analyzed, no significant difference between the SUR and BOT total carbon (excluding zooplankton) exists. Nevertheless, if we split up the total carbon into its components, the resulting pie graph (Fig. 4) shows a slightly higher phytoplankton carbon content in SUR and conversely a higher heterotrophic component (HPP, HNF and ciliates) in BOT.

A comparison of the carbon concentrations of icecover and ice-free periods in 1997 and 1998 results in a significant difference (ANOVA, $\mathrm{P}<0.05$ in SUR and $\mathrm{P}$ $<0.02$ in BOT) with higher concentrations in summer. During summer 1996 the concentrations were lower than in the subsequent years (Fig. 5), but as we lack the data from the ice-cover period we did not include them in the statistical elaborations. Mixotrophic algae survive 
under the ice-cover in December, before the snow accumulation completely obscures the water column, also at the ice-water interface. It is from them that the carbon content found at the SUR under the ice derives (Pugnetti \& Bettinetti 1999, this isuue).

\section{SUR}
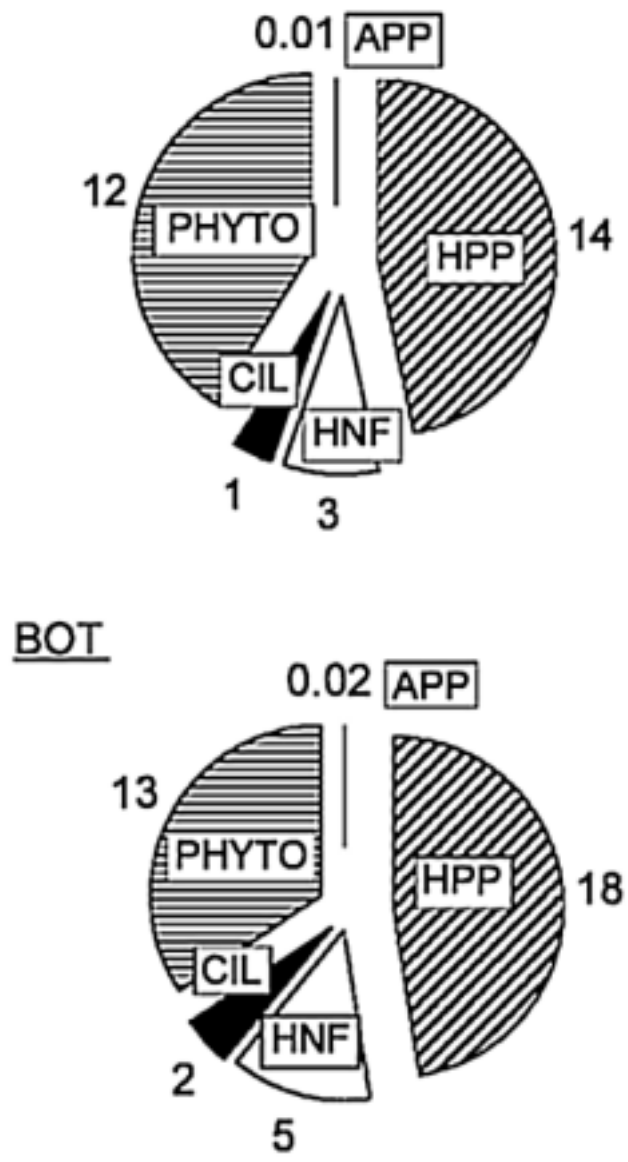

Fig. 4. Autotrophic and heterotrophic organisms of the microbial food web at the SUR ( $1 \mathrm{~m}$ under the surface) and BOT (1 $\mathrm{m}$ above the bottom) of Lake Paione Superiore expressed as a mean value of the three-year study. The values are in $\mu \mathrm{g} \mathrm{C}^{-1}$.

\section{DISCUSSION AND CONCLUSIONS}

The seasonal pattern of the organisms of the pelagic food web of Lago Paione Superiore shows a cycle characterized by an increase in carbon from the beginning of the ice-free period to mid-September, followed by a consistent decrease during ice-cover. Apparently the ice does not have a strong negative effect on the presence at SUR of the phytoplankton; some of them, like Dinobryon, show a peak in winter 1997 which suggests that these peculiar organisms can grow in nature with low light. However, as light has a regulatory effect on phagotrophy, its considerable reduction due to the accumulation of snow on the ice explains the decline of mixotrophic organisms at certain dates during winter. Under laboratory conditions (Jones \& Rees 1994) Dinobryon appears to be an obligate phototroph in the sense that it ceases its activity if placed in the dark for a period longer than one day. Temperature too has an influence on the uptake rate of Dinobryon: at $5{ }^{\circ} \mathrm{C}$ the Dinobryon sertularia clearance rate was lower than at $20^{\circ} \mathrm{C}$ in uptake experiments (Jones \& Rees 1994). In LPS the low temperature does not have a negative influence on the abundance of Dinobryon, although we have no data on the uptake activity under the ice. We must remember that the advantage of phagotrophy is the exploitation of an unfavorable environment to obtain essential resources (Veen 1991) and this is the case of our oligotrophic high mountain lake, where inorganic carbon $(0.7$ $\mathrm{mg} \mathrm{l}^{-1}$ ), nitrogen and phosphorus are low (The MOLAR Water Chemistry Group 1999, this issue).

The $\mathrm{A} / \mathrm{H}$ ratio low values demonstrate the prevalence of heterotrophic carbon in LPS. In the oligotrophic lake La Caldera this ratio fluctuated around 1 during the three years of study due to changes in the community structure, which was strongly influenced by different precipitation regimes (Medina-Sánchez et al. 1999, this issue). As a matter of fact the stability in the dominance of heterotrophic organisms (also not including zooplankton) is an exception, if compared with the other lakes included in the MOLAR project, where the autotrophic organisms generally prevail.

The low $\mathrm{A} / \mathrm{H}$ ratios are due to low algal carbon and might be the result of light inhibition of algal growth. At $2200 \mathrm{~m}$, in this clear water lake, the underwater PAR near the surface can exceed $1200 \mu \mathrm{E} \mathrm{m} \mathrm{m}^{-2} \mathrm{~s}^{-1}$, which might likely cause an inhibition effect on growth of phytoplankton in most of the water column.

As appears from the activity measurements performed in 1997 and 1998 (Callieri \& Bertoni, in prep.), the presence of Daphnia in the lake reduces drastically phytoplankton production, bacterial production and protozoa grazing on bacteria. The decrease in biomass and activity of organisms in the size range from less than $1 \mu \mathrm{m}$ to more than $100 \mu \mathrm{m}$ and the occurrence of a large spectrum filter feeder like Daphnia is more than a coincidence. Cladocerans have very broad niches and may eat pico-, nanoplankton and small ciliates (Gophen \& Geller 1984; Lampert 1987; Jürgens 1994). Though we did not measure zooplankton grazing activity, from all the other data available and from observation of well-fed individuals with full guts we hypothesized a top-down control of Daphnia on phytoplankton and on the microbial loop. Furthermore, the different situations of August 1997 (when Daphnia biomass was still low) and August 1998 (when Daphnia dominated) seem well related to the different levels of food items (microorganism carbon) reached in the corresponding periods, being higher in 1997 than in 1998 (Fig. 1, BOT). The control on phytoplankton biomass by Daphnia, suggested in previous studies from observation of the mirror-shaped curves of phyto- and zooplankton (Pugnetti 


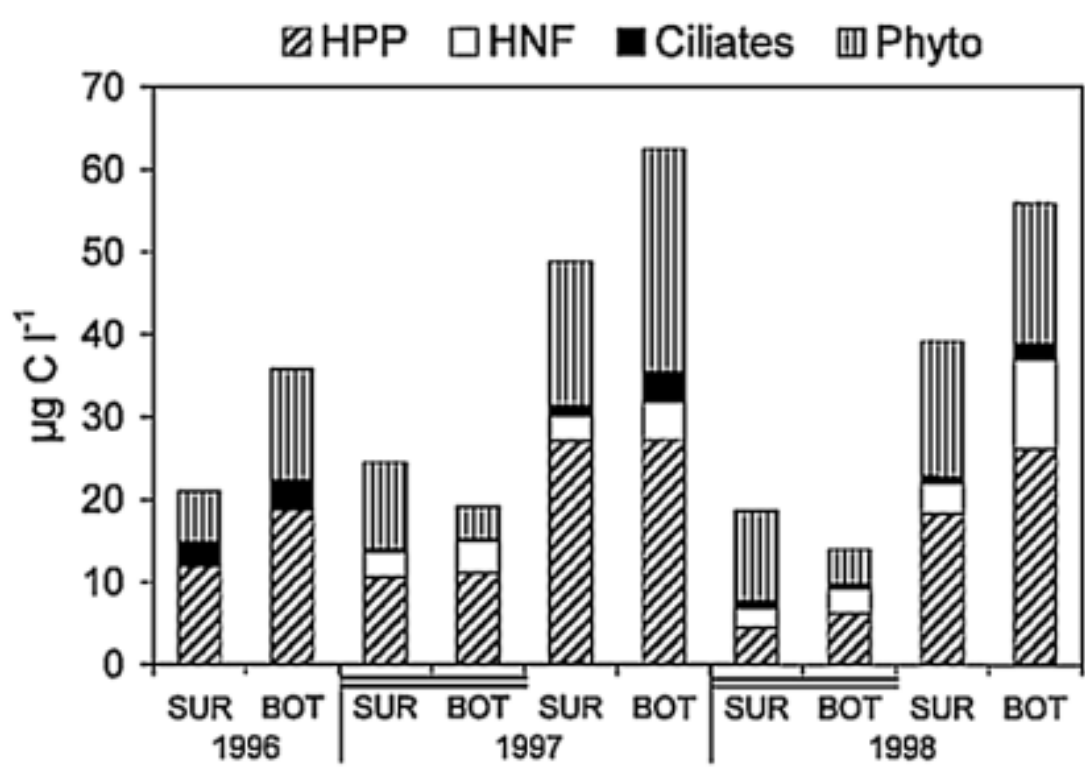

Fig. 5. Mean carbon values of the microorganisms of the microbial food web (APP, HPP, HNF, ciliates, phytoplankton) in the ice-free and ice-cover (double line) periods at the SUR (1m under the surface) and BOT (1 $\mathrm{m}$ above the bottom) of Lake Paione Superiore.
\& Bettinetti 1995; Cammarano \& Manca 1997), can be extended to the microorganisms of the microbial loop. It is likely that protozoa are an important source of fatty acids and sterols, thus representing a supplementary diet to enhance survival, growth and fecundity (Stoecker \& McDowell Capuzzo 1990) especially during periods of nutrient limitation (Sanders et al. 1996). In the oligotrophic LPS a diet which also includes protozoa could give Daphnia a further chance of survival. In similar extreme environments, like Antarctica, with limited primary production, the microbial food webs are an important source of nutrition for metazoans (Bröckel 1981; Buck \& Garrison 1988). A visual inspection of Daphnia indicates that they are well-fed, although there is a general depletion of eggs, probably related to the CyclopsDaphnia feeding interactions (Manca \& Comoli 1999, this issue). Food is probably not so scarce in Lago Paione Superiore. If we take microorganism carbon concentration as a measure of food availability (chlorophyll- $a$ is not a good measure of food in this lake; Cammarano \& Manca 1997; Pugnetti \& Bettinetti 1999, this issue), we find that the Daphnia population starts to grow when levels are above the threshold limit reported in literature for large-bodied species (Gliwicz 1990).

The importance of Daphnia in LPS could also extend to bacteria because the protozoan control of the bacterial production occurs only in July - early August, as demonstrated by bacterial production measurements and protozoa grazing (Callieri \& Bertoni, in prep.). The protozoa bacterivory in 1997 is responsible for $27 \mu \mathrm{g} \mathrm{C}$ $\mathrm{l}^{-1} \mathrm{~d}^{-1}$ in absence of Daphnia and for only $0.3 \mu \mathrm{g} \mathrm{C}^{-1} \mathrm{~d}^{-1}$ when Daphnia increases. Other Authors (Šimek et al. 1990; Vaquè \& Pace 1992; Jürgens 1994) have emphasized that Cladocerans become the main consumers of bacterial production during population peaks. Another observation is that in 1997 and 1998 the decrease in carbon food items is not restricted near the bottom, where Daphnia was present in the morning, during samplings. This could indicate that the predators migrate, in the dark, along the water column (Ringelberg 1993).

In conclusion, the data of the seasonal changes in the organisms of the microbial loop, phyto- and zooplankton, and of their relative contribution to the organic carbon in the food web of Lake Paione Superiore, are evidence of the existence of a well-defined succession. The carbon partitioning shows the dominance of heterotrophic over autotrophic organisms, near the surface and the bottom. The key organisms are bacteria, flagellates and Daphnia; in the absence of fish this Cladoceran shows a peak in September during which it exerts a topdown control of the smaller organisms. Mixotrophic rather than heterotrophic flagellates occupy the nearsurface layers during the ice-cover. Bacteria, thanks to the formation of long filaments, can contribute significantly $(\sim 50 \%)$ to the carbon in the microbial food web.

\section{ACKNOWLEDGMENTS}

This research was supported by the Commission of the European Community (project MOLAR ENV4CT95-0007). We wish to thank G. Tartari, A. Lami, A. Marchetto, M. Contesini for their work in the field and Jan Fott and Presentación Carrillo for comments on the manuscript.

\section{REFERENCES}

Amblard, C., G. Bourdier, T. Sime-Ngando, S. Rachiq \& J.F. Carrias. 1994. Diel and vertical variations of the microbial stocks (bacteria, heterotrophic flagellates, ciliates, phytoplankton) and their relative activities. Arch. Hydrobiol. Beih., 41: 125- 144. 
Amblard, C., J.F. Carrias, G. Bourdier \& N. Maurin. 1995. The microbial loop in a humic lake: seasonal and vertical variations in the structure of the different communities. Hydrobiologia, 300/301: 71-84.

Azam, F., T. Fenchel, J.G. Field, J.S. Gray, L.A. Meyer-Reil \& F. Thingstad. 1983. The ecological role of water-column microbes in the sea. Mar. Ecol. Prog. Ser., 10: $257-$ 263.

Beaver, J.R., T.L. Crisman \& R.W. Bienert. 1988. Distribution of planktonic ciliates in highly coloured subtropical lakes: comparison with clearwater ciliate communities and the contribution of mixotrophic taxa to total autotrophic biomass. Freshwat. Biol., 20: 51-60.

Bettinetti, R. 1994. Variazione stagionale e distribuzione verticale del fitoplancton in due laghi alpini (Lago Paione Superiore e Lago Paione Inferiore, Val d'Ossola). Tesi di Laurea, Università degli Studi di Milano: 156 pp.

Bianchini, M. 1952. La Val Bognanco. Appunti di Geografia. Bol.soc. Geograf. Ital., ser. VIII: 118-135.

Bröckel K. von 1981. The importance of nanoplankton within the Antarctic pelagic ecosystem. Kiel. Meeresforsch. Sonderh., 5: 61-67.

Buck, K.R. \& D.L. Garrison. 1988. Distribution and abundance of choanoflagellates (Acanthoecidae) across the iceedge zone in the Weddell Sea, Antarctic. Mar. Biol., 98: 263-269.

Callieri, C. \& R. Bertoni. 1999. Organic carbon and microbial food web assemblages in an oligotrophic alpine lake. In: Straškrabová, V., C. Callieri \& J Fott (Eds), Pelagic food web in mountain lakes. MOuntain LAkes Research Program. J. Limnol., 58(2): 136-143.

Callieri, C. \& R. Bertoni. Microbial assemblages and dissolved organic carbon in a simplified natural system: activity changes with and without Daphnia longispina: (in prep.).

Cammarano, P. \& M. Manca. 1997. Studies on zooplankton in two acidified high mountain lakes in the Alps. Hydrobiologia, 345: 97-109.

Carrick, H. J., G.L. Fahnenstiel, E.F. Stoermer \& R. G. Wetzel. 1991. The importance of zooplankton-protozoan trophic couplings in Lake Michigan. Limnol. Oceanogr., 36: $1335-1345$.

Gliwicz, Z.M. 1990. Food thresholds and body size in cladocerans. Nature, 343: 638-640.

Gophen, M. \& W. Geller. 1984. Filter mesh size and food particle uptake by Daphnia. Oecologia (Berlin), 64: 408412.

Hadas, O. \& T. Berman. 1998. Seasonal abundance and vertical distribution of protozoa (flagellates, ciliates) and bacteria in Lake Kinneret, Israel. Aquat. Microb. Ecol., 14: 161170.

Isaksson, A. 1998. Phagotrophic phytoflagellates in lakes - a literature review. Arch. Hydrobiol. Spec. Issues Advanc. Limnol., 51: 63-90.

Jones, R.I. \& S. Rees. 1994. Influence of temperature and light on particle ingestion by the freshwater phytoplagellate $D i$ nobryon. Arch. Hydrobiol., 132: 203-211.

Jürgens, K. 1994. Impact of Daphnia on planktonic microbial food web. A review. Mar. Microb. Food Webs, 8: 295324

Jürgens, K., H. Arndt \& H. Zimmermann. 1997. Impact of metazoan and protozoan grazers on bacterial biomass distribution in microcosm experiments. Aquat. Microb. Ecol., 12: $131-138$

Lampert, W. 1987. Feeding and nutrition in Daphnia. In: R.H. Peters \& R. de Bernardi (Eds), Daphnia. Mem. Ist. ital. Idrobiol., 45: 143-192.

Manca, M. \& P. Comoli. 1999. Studies on zooplankton of Lago Paione Superiore. In: Straškrabová, V., C. Callieri \& J Fott (Eds), Pelagic food web in mountain lakes. MOun- tain LAkes Research Program. J. Limnol., 58(2): 131135.

Mathes, J. \& H. Arndt. 1995. Annual cycle of protozooplankton (ciliates, flagellates and sarcodines) in relation to phyto- and metazooplankton in Lake Neumühler See (Mecklenburg, Germany). Arch. Hydrobiol., 134: 337358.

Mosello, R., A. Boggero, M. Carmine, A. Marchetto, A. Sassi \& G.A. Tartari. 1994. Ricerche idrochimiche sui laghi alpini delle valli Ossola e Sesia (Alpi Pennine e Lepontine). Documenta Ist. ital .Idrobiol., 46: $436 \mathrm{pp}$.

Mosello, R., A. Lami, P. Guilizzoni, M. Manca, A.M. Nocentini, A. Pugnetti, A. Boggero, A. Marchetto, G.A. Tartari, R. Bettinetti, M. Bonardi and P. Cammarano. 1993. Limnological studies on two acid sensitive lakes in the Central Alps (Lakes Paione Superiore and Paione Inferiore, Italy). Mem. Ist. ital. Idrobiol., 51: 127-146.

Nagata, T. 1988. The microflagellate-picoplankton food linkage in the water column of Lake Biwa. Limnol. Oceanogr., 33: 504-517.

Nagata, T., K. Takay, K. Kawabata, M. Nakanishi \& J. Urabe. 1996. The trophic transfer via a picoplankton-flagellatecopepod food chain during a picocyanobacterial bloom in Lake Biwa. Arch. Hydrobiol., 137(2): 145-160.

Pace, M.L., G.B. McManus \& S.E.G. Findlay. 1990. Planktonic community structure determines the fate of bacterial production in a temperate lake. Limnol. Oceanogr. 35 795-808.

Pomeroy, L.R. 1974. The ocean's food web, a changing paradigm. Bio Science, 24(9): 499-504.

Porter, K.G. 1988. Phagotrophic phytoflagellates in microbial fodd webs. Hydrobiologia, 159: 89-97.

Porter, K.G. 1996. Integrating the microbial loop in the classical food chain into a realistic planktonic food web. In: Polis, G.A. \& Winemiller, K.O. (Eds), Food webs: integration of patterns and dynamics. Chapman and Hall, New York: 51-59.

Pugnetti, A. \& R. Bettinetti. 1995. The phytoplankton communities of two acid sensitive alpine lakes (lakes Paione, Central Alps, Italy). Mem. Ist. ital. Idrobiol., 53: 39-52.

Ringelberg, J. 1993. Diel vertical migration of zooplankton. Arch. Hydrobiol., 39: 222 pp.

Sanders, R.W., C.E. Williamson, P. Stutzman, R. Moeller, C.E. Goulden \& R. Aoki-Goldsmith. 1996. Reproductive success of "herbivorous" zooplankton fed algal and non algal resources. Limnol. Oceanogr., 41: 1295-1305.

Sieburth, J.McN. \& P.G. Davis. 1982. The role of heterotrophic nanoplankton in the grazing and nurturing of planktonic bacteria in the Sargasso and Caribbean seas. Ann. Inst. Oceanogr., 58: 285-296.

Šimek, K., J. Bobkova, M. Macek, J. Nedoma \& R. Psenner. 1995. Ciliate grazing on picoplankton in a eutrophic reservoir during the summer phytoplankton maximum: a study at a species and community level. Limnol. Oceanogr., 40: 1077-1090.

Šimek, K., P. Hartman, J. Nedoma, J. Pernthaler, D. Springmann, J. Vrba \& R. Psenner. 1997. Community structure, picoplankton grazing and zooplankton control of heterotrophic nanoflagellates in a eutrophic reservoir during the summer phytoplankton maximum. Aquat. Microb. Ecol., 12: $49-63$

Šimek, K., M. Macek, J. Seda \& V. Vyhnálek. 1990. Possible food chain relationship between bacterioplankton protozoans and cladocerans in a reservoir. Int. Revue Ges. Hydrobiol., 75: 583-596.

Stockner, J.G. \& K.G. Porter. 1988. Microbial food webs in freshwater planktonic ecosystems. In: S.R. Carpenter (Ed.), Complex interactions in lake communities. Springer-Verlag, N.Y.:69-83.

Stockner, J.G \& K.S. Shortreed. 1991. Phototrophic picoplankton: community composition abundance and distri- 
bution across a gradient of oligotrophic British Columbia and Yukon Territory lakes. Int. Revue ges. Hydrobiol., 76: 581-601.

Stoecker, D.K. \& J. McDowell Capuzzo. 1990. Predation on protozoa: its importance to zooplankton. J. Plankton Res., 12: 891-908.

Straškrabová, V., C. Callieri, P. Carrillo, L. Cruz-Pizarro, J. Fott, P. Hartman, M. Macek, J.M. Medina-Sánchez, J. Nedoma \& K. Simek. 1999. Investigations on pelagic food webs in mountain lakes - aims and methods. In: Straškrabová, V., C. Callieri \& J Fott (Eds), Pelagic food web in mountain lakes. MOuntain LAkes Research Program. J. Limnol., 58(2): 77-87.

The MOLAR Water Chemistry Group. 1999. The MOLAR Project: atmospheric deposition and lake water chemistry. In: Straškrabová, V., C. Callieri \& J Fott (Eds), Pelagic food web in mountain lakes. MOuntain LAkes Research Program. J. Limnol., 58(2): 88-106.

Vaqué, D. \& L.M. Pace. 1992. Grazing on bacteria by flagellates and cladocerans in lakes of contrasting food-web structure. J. Plankton Res., 14: 307-321.

Veen, A. 1991. Ecophysiological studies on the phagotrophic phytoplagellate Dinobryon divergens IMHOF. Ph.D. Thesis, University of Amsterdam. The Netherlands.

Weisse, T., H. Müller, R.M. Pinto-Coelho, A. Schweizer, D. Springmann \& G. Baldringer. 1990. Response of the microbial loop to the phycoplankton spring bloom in a large prealpine lake. Limnol.Oceanogr., 35: 781-794.

Williams, P.J. LeB. 1981. Incorporation of microeterotrophic processes into the classical paradigm of the planktonic food web. Kieler Meeresforsch. Sonderh., 5: 1-28. 